\title{
Sodium Manganese Oxide Thin Films as Cathodes for Na-Ion Batteries
}

Loïc Baggetto $^{\mathrm{a}, *}$, Kyler J. Carroll ${ }^{\mathrm{b}}$, Raymond R. Unocic ${ }^{\mathrm{a}}$, Craig A. Bridges ${ }^{\mathrm{c}}$, Ying Shirley Meng ${ }^{\mathrm{b}}$, Gabriel M. Veith ${ }^{\mathrm{a}, *}$

${ }^{a}$ Materials Science and Technology Division, Oak Ridge National Laboratory, Oak Ridge TN 37831, USA

${ }^{\mathrm{b}}$ Department of NanoEngineering, University of California San Diego, La Jolla, CA, 92109, USA

${ }^{\mathrm{c}}$ Chemical Sciences Division, Oak Ridge National Laboratory, Oak Ridge TN 37831 , USA

This paper presents the fabrication and characterization of sodium manganese oxide cathode thin films for rechargeable Na-ion batteries. Layered oxide compounds of nominal compositions $\mathrm{Na}_{0.6} \mathrm{MnO}_{2}$ and $\mathrm{Na}_{1.0} \mathrm{MnO}_{2}$ have been prepared by radio frequency magnetron sputtering and post-annealing at high temperatures under various conditions. The $\mathrm{Na}_{0.6} \mathrm{MnO}_{2}$ thin films possess either a hexagonal or orthorhombic structure while the $\mathrm{Na}_{1.0} \mathrm{MnO}_{2}$ films crystallize in a monoclinic structure, as shown by X-ray diffraction and X-ray absorption spectroscopy results. The potential profiles of the film cathodes are characterized by features similar to those measured for the powders and exhibit reversible storage capacities in the range of 50-60 $\mu \mathrm{Ah} \mathrm{cm}^{-2} \mu \mathrm{m}^{-1}$, which correspond to about 120-140 $\mathrm{mAh} \mathrm{g}^{-1}$, and are maintained over 80 cycles.

\section{Introduction}

Rechargeable batteries are essential components for powering ever-more demanding portable electronic devices such as laptops and smart phones (1). For these applications lithium-ion technology is highly attractive due to its higher gravimetric and volumetric energy densities, and high rate performance (1). Batteries are also attracting a great deal of attention for static grid applications to prevent massive power blackouts and load stabilization (2). For this application, sodium-ion batteries are good candidates as they can be based on abundant, low cost and low toxicity electrode materials such as $\mathrm{Na}, \mathrm{Fe}$ and $\mathrm{Mn}(3)$.

Layered Na-ion cathode materials investigated thus far are divided in two main groups depending upon the stacking of the layers (3-5). The first group, denoted O3, is formed by layers of $\mathrm{MO}_{6}$ octahedra with $\mathrm{ABC}$ oxygen stacking separated by $\mathrm{Na}$ slabs in which $\mathrm{Na}$ cations occupy octahedral sites. Examples of materials with this structure are $\mathrm{LiCoO}_{2}$ or $\mathrm{NaCoO}_{2}$. The second group, denoted $\mathrm{P} 2$, is formed of layers of $\mathrm{MO}_{6}$ octahedra with $\mathrm{AB}-\mathrm{BA}$ stacking separated by $\mathrm{Na}$ slabs in which $\mathrm{Na}$ occupies a prismatic site. A parent electrode material adopting this structure is hexagonal $\mathrm{Na}_{0.7} \mathrm{MnO}_{2}$, also denoted $\alpha$ $\mathrm{Na}_{0.7} \mathrm{MnO}_{2}$ (6). In general, the $\mathrm{P} 2$ structure offers much larger reversible capacities than the $\mathrm{O} 3$ (3). Given the abundance of $\mathrm{Mn}$ and Fe in the Earth's crust, compounds based on these elements are particularly relevant for low cost energy storage alternatives such as Na-ion batteries. 
The first report of the electrochemical intercalation properties of $\mathrm{Na}_{\mathrm{x}} \mathrm{MnO}_{2}$ materials by Delmas et al. indicated that $\mathrm{Na}_{0.44} \mathrm{MnO}_{2}$ and $\mathrm{P} 2 \mathrm{Na}_{0.7} \mathrm{MnO}_{2}$ are excellent candidates for applications as cathode materials, especially $\mathrm{Na}_{0.7} \mathrm{MnO}_{2}$ (7). Several years later, the P2 $\mathrm{Na}_{\mathrm{x}} \mathrm{MnO}_{2}$ system was revisited by Caballero et al. which reported that the composition $\mathrm{Na}_{0.6} \mathrm{MnO}_{2}$ was stable as a hexagonal P2 structure at temperatures as high as $800^{\circ} \mathrm{C}$ (8). This was unexpected as the $\mathrm{P} 2 \mathrm{Na}_{0.7} \mathrm{MnO}_{2}$ phase was found to convert into an orthorhombic $\beta$ phase at temperatures above $600^{\circ} \mathrm{C}$ (6). This apparent difference might be explained by the slow conversion process, as reported by Parant el al., in which the transformation temperatures from $\alpha$ to $\beta$ and from $\beta$ to $\alpha$ were found to be separated by $100^{\circ} \mathrm{C}$ at the very slow rate of $10^{\circ} \mathrm{C} \mathrm{hr}^{-1}$ (6). Moreover, the initial work by Delmas et al. reporting somewhat low electrochemical storage capacities for monoclinic (O’3) $\mathrm{NaMnO}_{2}$ (4) was recently revisited by Ma et al. who showed that this structure is offering large capacities $(200 \mathrm{mAh} / \mathrm{g})$ when cycling up to $3.8 \mathrm{~V}$ at low rates (9).

In the light of these reports, we have opted to investigate the P2 $\mathrm{Na}_{0.6} \mathrm{MnO}_{2}$ and O'3 $\mathrm{NaMnO}_{2}$ structures as cathode materials in the form of thin films which may aid understanding diffusion and surface reactivity. The as deposited thin films were annealed using various conditions to influence the structure and electrochemical properties. The materials structures were characterized with various techniques: (X-ray diffraction (XRD), scanning electron microscopy (SEM), transmission electron microscopy (TEM), and X-ray absorption spectroscopy (XAS). Their electrochemical properties were measured with galvanostatic cycling.

\section{Experimental}

\section{Samples preparation}

$\mathrm{Na}-\mathrm{Mn}-\mathrm{O}$ thin films were deposited onto Pt-coated alumina substrates $(1 \mathrm{~cm}$ diameter, Valley Design) by RF magnetron sputtering using 2" diameter homemade targets. The sputtering targets were sintered from $\mathrm{Mn}_{2} \mathrm{O}_{3}$ and $\mathrm{Na}_{2} \mathrm{CO}_{3}$ precursors to yield final ratios of $\mathrm{Na} / \mathrm{Mn}$ of 0.4 and 0.7 , as determined by energy dispersive $\mathrm{x}$-ray analysis (EDX). Sputtering at 5mTorr Ar pressure and $80 \mathrm{~W}$ RF power yielded Na-enriched thin films with $\mathrm{Na} / \mathrm{Mn}$ ratios of 0.6 and 1.0 determined by EDX, respectively. Deposition rates were measured with a quartz microbalance and film thicknesses were varied from 0.4 to $6 \mu \mathrm{m}$ depending on the characterization. In order to investigate the effects of post-annealing on the $\mathrm{Na}_{\mathrm{x}} \mathrm{MnO}_{2}$ material properties, as described by Parant et al. (6) and Caballero et al. (8), the thin films with the $\mathrm{Na} / \mathrm{Mn}$ ratio of 0.6 were annealed at $750^{\circ} \mathrm{C}$ in pure $\mathrm{O}_{2}$ for 1 hour and subsequently quenched to room temperature. Post-annealing at $550^{\circ} \mathrm{C}$ in pure $\mathrm{O}_{2}$ for 2 or 4 hours was conducted on some of these samples, subsequently followed by quenching to room temperature. The thin films of $\mathrm{Na} / \mathrm{Mn}$ ratio of 1.0 were annealed at $750^{\circ} \mathrm{C}$ in pure $\mathrm{O}_{2}$ for 1.5 hours and subsequently quenched to room temperature. After preparation, the thin film samples were stored inside an Ar-filled glovebox to prevent reaction with moisture.

\section{Characterization}

SEM characterization of the thin film electrodes was performed using a Hitachi S4800 cold-field emission SEM that is equipped with an EDAX silicon drift EDX detector. Elemental analysis using EDX was performed using $\mathrm{Na}$ and $\mathrm{Mn}$ K-lines. XRD scans were acquired with a Scintag Pad V diffractometer employing a $\mathrm{Cu} \mathrm{K}_{\alpha}$ source and energy dispersive detector, to minimize Mn fluorescence, typically over ranges from 15 to $70^{\circ}$ 
20. Rietveld refinements of the patterns were performed using the GSAS software. Highresolution TEM (HRTEM) imaging was performed using a Hitachi HF3300 S/TEM instrument that was operated at $300 \mathrm{kV}$.

XAS at the Mn K-edge (6539 eV) was carried out at the National Synchrotron Light Source at beamline X-11B. Measurements were recorded from Kapton-sealed samples in X-ray fluorescence mode with a passivated implanted planar silicon (PIPS) detector. $\mathrm{Mn}_{2} \mathrm{O}_{3}\left(99.9 \%\right.$, Cerac) and $\mathrm{MnO}_{2}(99.997 \%$, Puratronic, Alfa Aesar) were measured as references. After detuning the channel-cut monochromator by $30 \%$ before measuring the edge, a total of 5 scans were averaged. The XAS spectra were analyzed using the Iffefit and Horae software packages $(10,11)$. The extended X-ray absorption fine structure (EXAFS) region of the spectra was fit to ab initio theoretical standards (12).

Electrochemical characterization was conducted with two-electrode coin cells (2032 hardware, Hohsen) assembled inside an Ar-filled glovebox. The cells consisted of pure $\mathrm{Na}$ as counter electrode, two pieces of glass fiber separator impregnated by the electrolyte solution of $1 \mathrm{M} \mathrm{NaClO}_{4}$ dissolved in propylene carbonate (PC) / ethylene carbonate (EC) / dimethoxyethane (DME) in a ratio of $15 / 15 / 70 \mathrm{wt} \%$, and the thin film cathode as working electrode. Galvanostatic cycling was performed on a Maccor 4000 series between 2 and $3.5 \mathrm{~V}$ vs. $\mathrm{Na} / \mathrm{Na}^{+}$using currents of 5 to $10 \mu \mathrm{A}$ for electrodes with a surface area of 0.785 $\mathrm{cm}^{2}$. Capacities are expressed in $\mu \mathrm{Ah}$ per $\mathrm{cm}^{2}$ footprint area per $\mu \mathrm{m}$ cathode thickness $\left(\mu \mathrm{Ah} \mathrm{cm}^{-2} \mu \mathrm{m}^{-1}\right)$.

\section{$\underline{\text { Results and Discussion }}$}

The morphology of the thin films can be seen in the SEM images presented in Figure 1. The as deposited films are initially amorphous and the surface topology is influenced by the surface roughness of the Pt-coated alumina substrates (not presented). Following a post-deposition annealing heat treatment at $750^{\circ} \mathrm{C}$ for $1 \mathrm{hr}$, the structure of the films of nominal composition $\mathrm{Na}_{0.6} \mathrm{MnO}_{2}$ (Figure 1a) consisted of high aspect ratio crystals that grew from the starting film in a 'bouquet' morphology. For the films post-annealed at $750^{\circ} \mathrm{C} / 550^{\circ} \mathrm{C}$ for $2 \mathrm{hrs}$ (Figure $1 \mathrm{~b}$ ), the individual crystals remain visible despite some evidence of sintering during the second annealing step at $550^{\circ} \mathrm{C}$. These results are consistent with the data of Tevar et al., who reported that $\mathrm{Na}_{\mathrm{x}} \mathrm{MnO}_{2}$ crystals of $\mathrm{Na} / \mathrm{Mn}$ ratios from 0.33 to 0.7 possess a similar crystalline rod-like morphology that can be attributed to their related crystallographic structures (13). In the case of these thin films, the peculiar 'bouquet' morphology arises from the crystal growth of the rods from the material deposited onto the substrate. In the case of the films of nominal composition $\mathrm{Na}_{1.0} \mathrm{MnO}_{2}$, Figure 1c, the crystals have a different morphology and do not contain elongated crystals. Instead the structure is reminiscent of small micron sized crystallites. This morphological difference is likely related to the differences in microstructure of $\mathrm{Na}$ richer O'3 microstructure.

Through quantitative EDX analyses, similar $\mathrm{Na} / \mathrm{Mn}$ ratios (nominal composition 0.6) are found for the initial ratios of 0.57 and $0.55 \mathrm{Na} / \mathrm{Mn}$ that were post-annealed at $750^{\circ} \mathrm{C}$ and $750^{\circ} \mathrm{C} / 550^{\circ} \mathrm{C}$, respectively. A ratio of 1.01 was determined for the sample of nominal composition 1.0. As demonstrated earlier for Li-ion cathode thin films, sputtering at low Ar pressure can induce film enrichment for relatively light elements such as Li $(14,15)$ and here $\mathrm{Na}$. The microstructure of particles resulting from the films has been studied by HRTEM (Figure 2). Lattice fringes of the nanorods formed in the samples of nominal composition $\mathrm{Na} / \mathrm{Mn}=0.6$ post-annealed at $750^{\circ} \mathrm{C}$ and $750 / 550^{\circ} \mathrm{C}$ are observed in Figures 
$2 \mathrm{a}$ and $2 \mathrm{~b}$. For the film of nominal composition $\mathrm{Na} / \mathrm{Mn}=1$, the morphology of the film particles are significantly different, Figure 2c, as presented earlier with SEM micrographs.
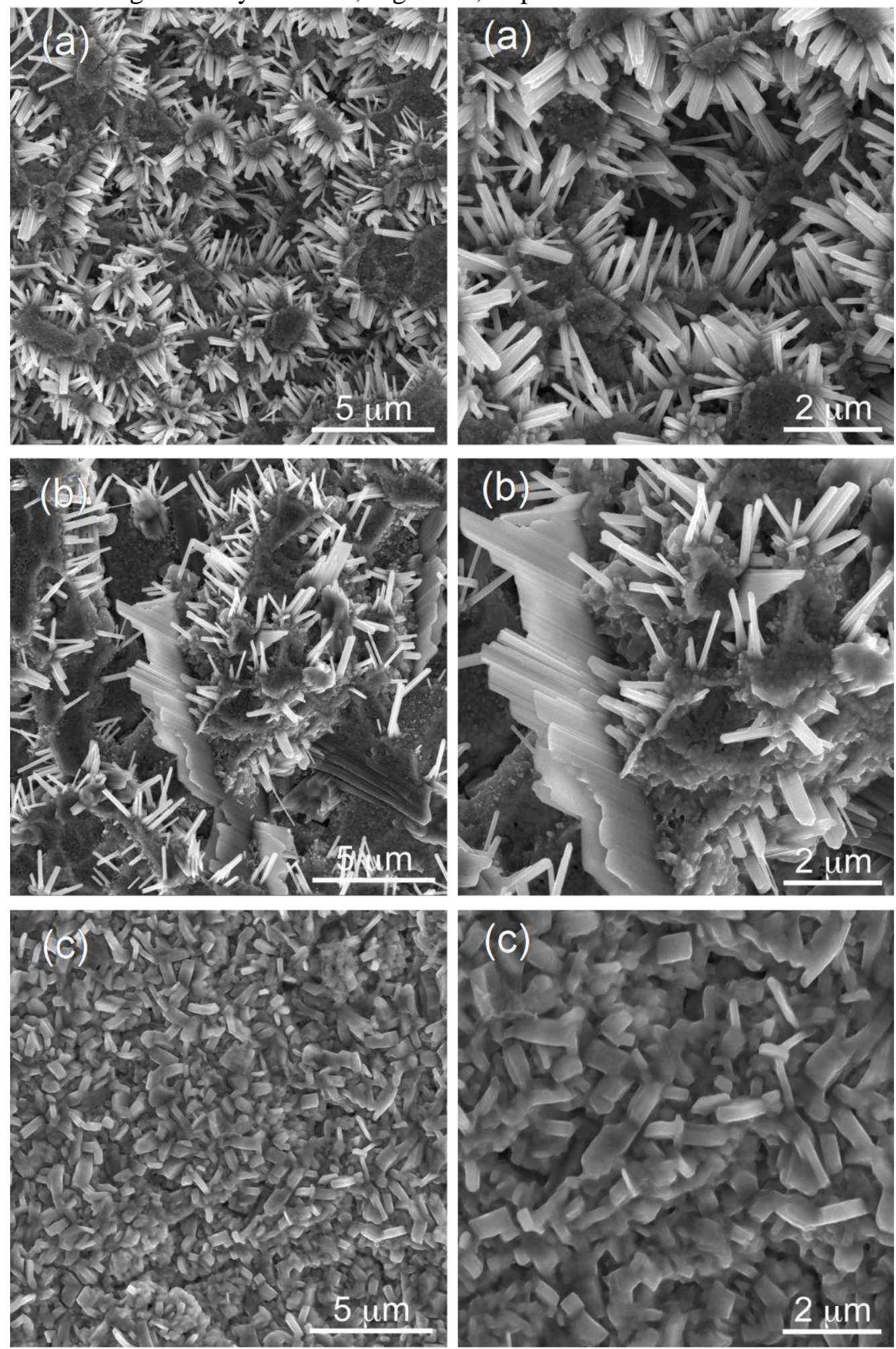

Figure 1. SEM images of (a) $\mathrm{Na}_{0.6} \mathrm{MnO}_{2} 750^{\circ} \mathrm{C} 1 \mathrm{hr}$, (b) $\mathrm{Na}_{0.6} \mathrm{MnO}_{2} 750^{\circ} \mathrm{C} 1 \mathrm{hr} / 550^{\circ} \mathrm{C} 2$ $\mathrm{hr}$ and (c) $\mathrm{NaMnO}_{2} 750^{\circ} \mathrm{C} 1.5 \mathrm{hr}$ thin film samples. 

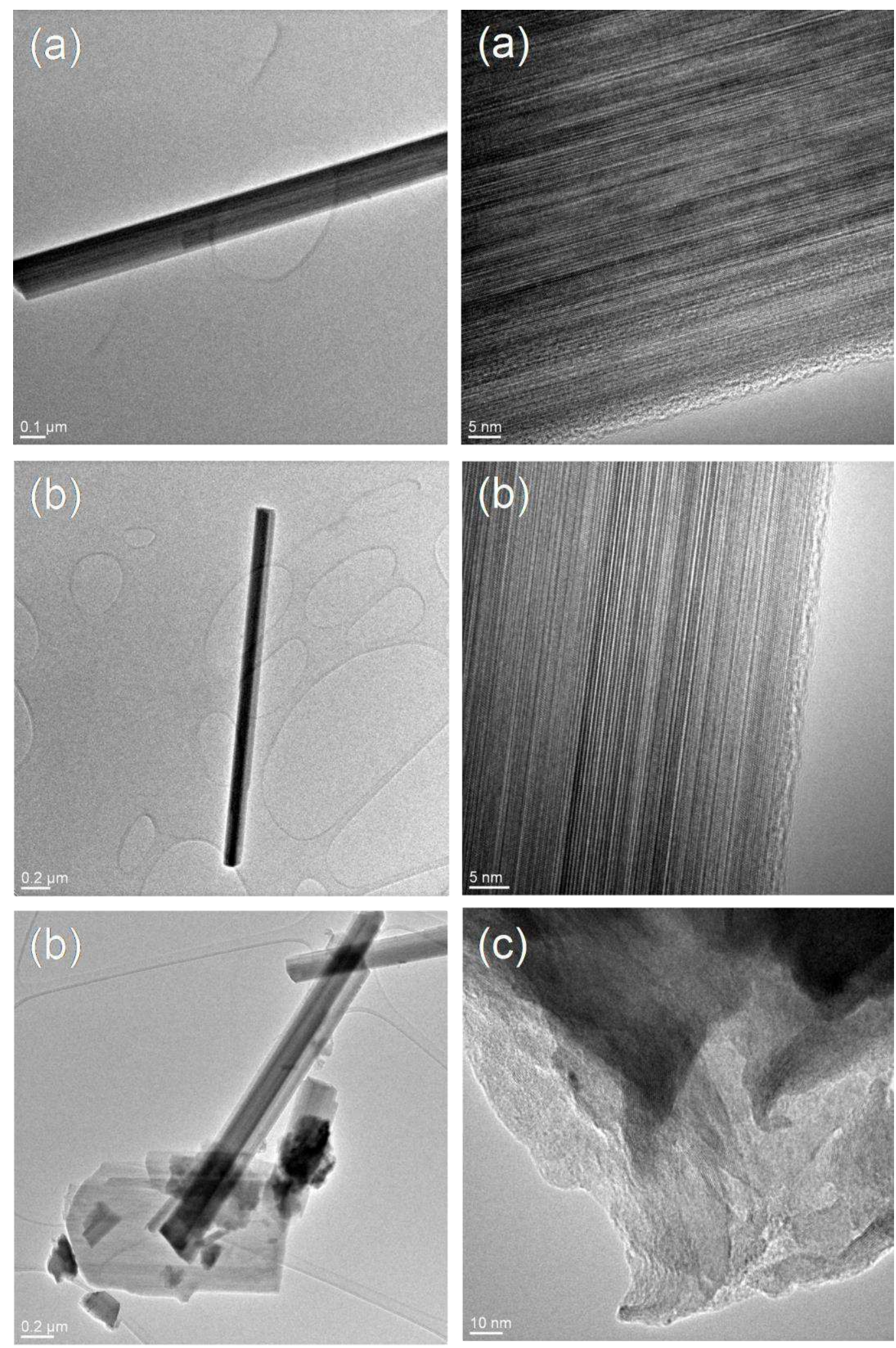

Figure 2. TEM images of (a) $\mathrm{Na}_{0.6} \mathrm{MnO}_{2} 750^{\circ} \mathrm{C} 1 \mathrm{hr}$, (b) $\mathrm{Na}_{0.6} \mathrm{MnO}_{2} 750^{\circ} \mathrm{C} 1 \mathrm{hr} / 550^{\circ} \mathrm{C} 2$ $\mathrm{hr}$ and (c) $\mathrm{NaMnO}_{2} 750^{\circ} \mathrm{C} 1.5 \mathrm{hr}$ thin film samples. 
For the $\mathrm{Na} / \mathrm{Mn}$ ratios of 0.6 , annealing at $750^{\circ} \mathrm{C}$ may produce an orthorhombic (6) or a hexagonal (9) phase. Post-annealing of this composition at $550^{\circ} \mathrm{C}$ is expected to produce the pure hexagonal phase if sufficiently long reaction times are allowed (6). For the films of nominal $\mathrm{Na} / \mathrm{Mn}$ ratio of 1.0 , annealing at $750^{\circ} \mathrm{C}$ should yield films with a monoclinic structure of composition $\mathrm{NaMnO}_{2}(6,7,9)$. The schematic representations of these structures are presented in Figure 3. The P2 structure (Figure 3a) is formed of layers of $\mathrm{MO}_{6}$ octahedra with $\mathrm{AB}-\mathrm{BA}$ stacking separated by $\mathrm{Na}$ slabs in which $\mathrm{Na}$ occupies a prismatic site. The orthorhombic structure (Figure $3 b$ ) is derived from P2 upon elongation of an axis and the presence of $\mathrm{Na}$ atoms slightly above and below plane of the $\mathrm{Na}$ slabs. The monoclinic structure denoted O'3 (Figure 3c), is formed by layers of $\mathrm{MO}_{6}$ octahedra with $\mathrm{ABC}$ oxygen stacking separated by $\mathrm{Na}$ slabs in which $\mathrm{Na}$ atoms occupy octahedral sites.

(a)
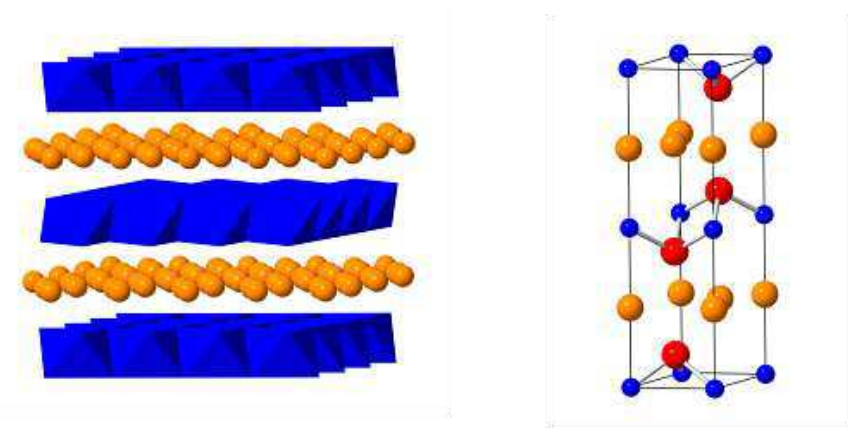

(b)
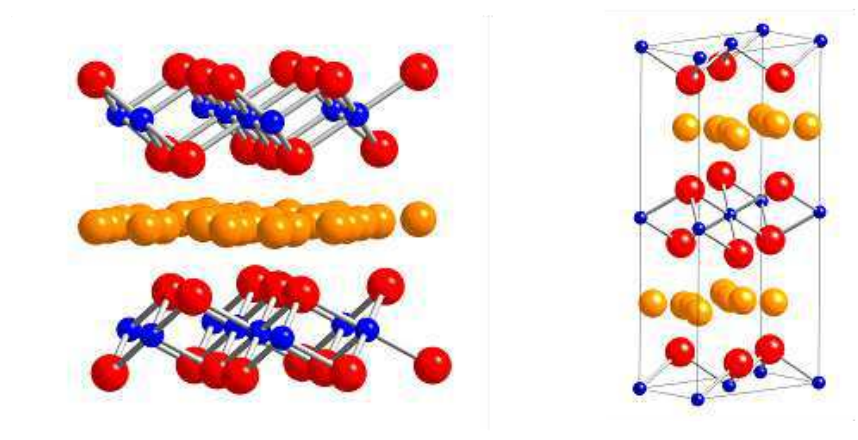

(c)
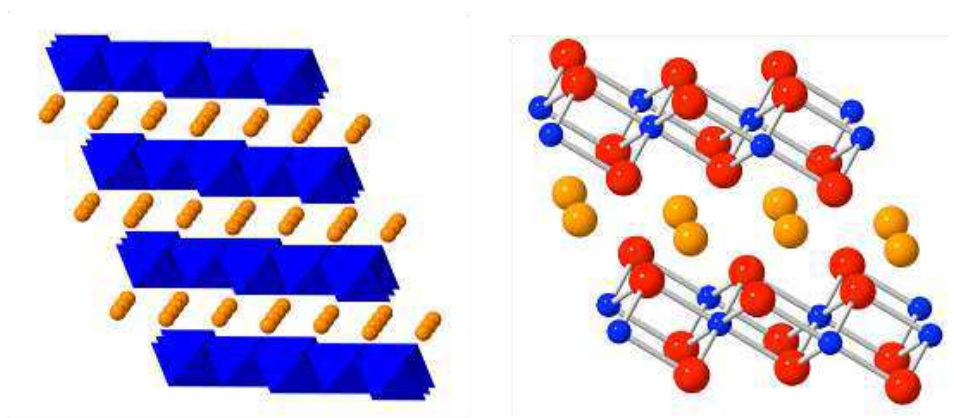

Figure 3. Schematic representation of (a) hexagonal $\mathrm{P} 2 \mathrm{Na}_{0.7} \mathrm{MnO}_{2}$, (b) orthorhombic $\mathrm{Na}_{0.68} \mathrm{MnO}_{2}$ derived from $\mathrm{Cmcm} \mathrm{Na}_{0.68} \mathrm{CoO}_{2}$ and (c) monoclinic O'3 $\mathrm{NaMnO}_{2}$ ideal crystallographic structures. Orange, blue and red atoms represent $\mathrm{Na}, \mathrm{Mn}$ and $\mathrm{O}$, respectively. 
The XRD patterns measured on the thin films are presented in Figure 4 for different $2 \theta$ regions of interest. The Miller indices are indicated next to the peak based on the hexagonal cell $(\mathrm{H})$ for the films of nominal composition 0.6 , and in the monoclinic cell (M) for the film of composition 1.0. The films of nominal composition 0.6 show very strong preferred orientation for crystallites with (002) planes parallel to the substrate. The resulting Rietveld refinements fitted with a spherical harmonic preferred orientation correction are given in Table 1. Due to the strong preferred orientation effects, it is difficult to directly determine whether the films post-annealed at $750^{\circ} \mathrm{C}$ are made of the hexagonal $\mathrm{P} 2$ or orthorhombic $\mathrm{Cmcm}$ structure. For the films post-annealed at $750^{\circ} \mathrm{C} / 550^{\circ} \mathrm{C}$ the diffraction peaks shift to larger $2 \theta$ values (Figure 4 ), which supports the formation of a smaller unit cell; this is particularly prominent for the (001) planes. Better refinement is obtained using a mixture of both phases, with a majority of orthorhombic structure ( $84 \mathrm{wt} \%$, Table 1). This result also suggests that the films made with a single post-annealing at $750^{\circ} \mathrm{C}$ may be formed of the orthorhombic structure, which is refined with a lower $\chi^{2}$ (Table 1 ). The decrease of the $\mathrm{c}$ axis after a second annealing at $550^{\circ} \mathrm{C}$ cannot be attributed to $\mathrm{Na}$ losses as the loss of $\mathrm{Na}$ would weaken the cohesion between the planes of $\mathrm{MnO}_{6}$ octahedra and result in larger c values. Instead, we suspect that the second annealing allows the partial elimination of defects such as stacking faults. For the films of nominal composition 1.0, the structure primarily consists of the monoclinic phase along with a small minority of hexagonal phase $(\sim 3 \mathrm{wt} \%)$

\section{Intensity (a.u.)}
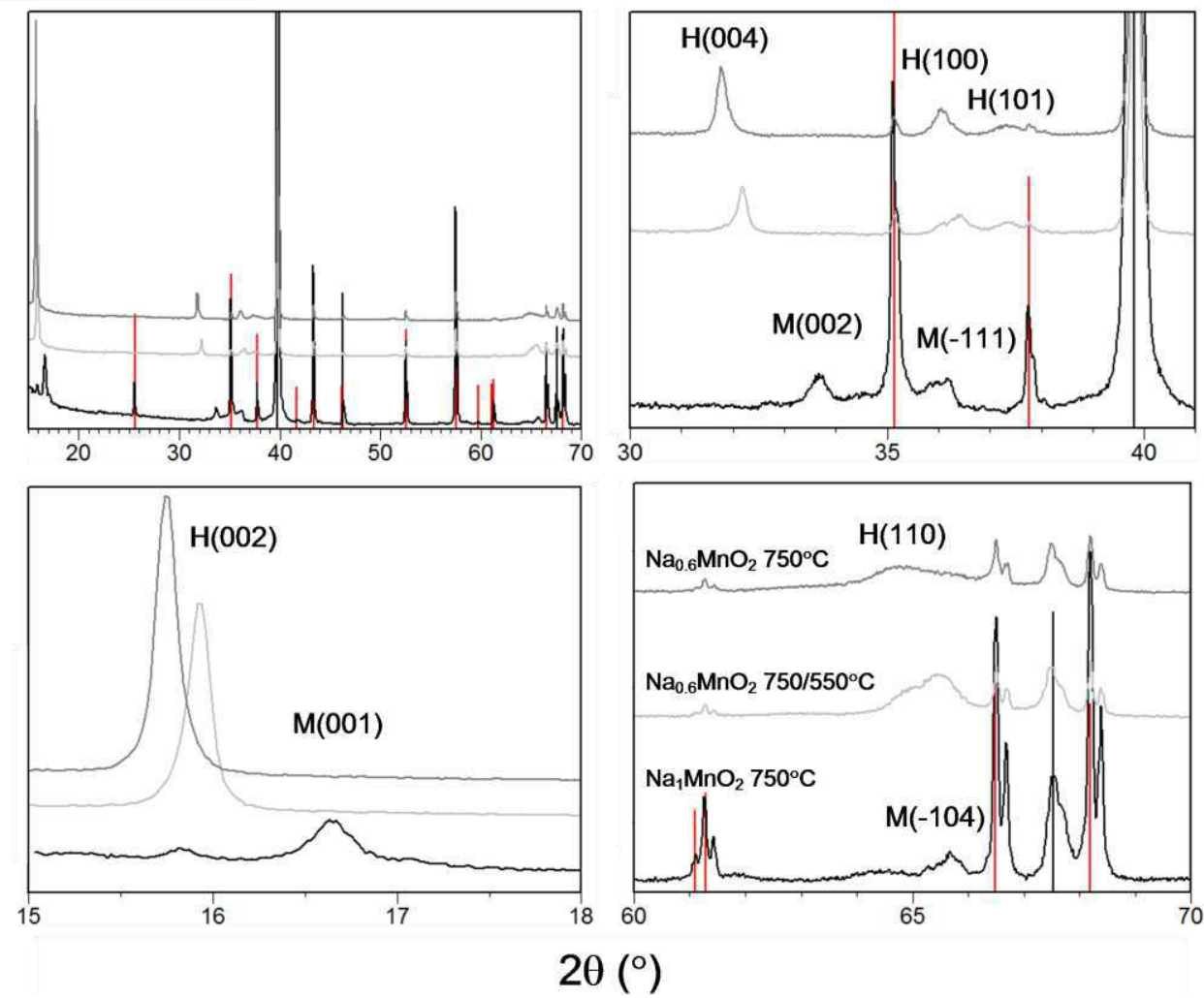

$2 \theta\left({ }^{\circ}\right)$

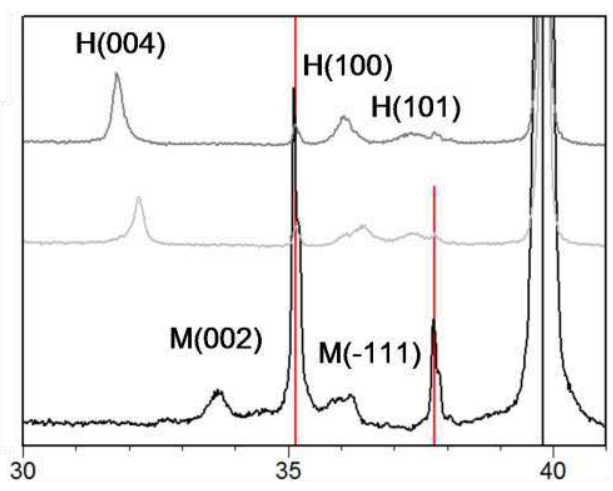

Figure 4. X-ray diffraction patterns of the various thin films samples, from top to bottom: $\mathrm{Na}_{0.6} \mathrm{MnO}_{2} 750^{\circ} \mathrm{C} 1 \mathrm{hr}, \mathrm{Na}_{0.6} \mathrm{MnO}_{2} 750^{\circ} \mathrm{C} 1 \mathrm{hr} / 550^{\circ} \mathrm{C} 2 \mathrm{hr}$ and $\mathrm{NaMnO}_{2} 750^{\circ} \mathrm{C} 1.5 \mathrm{hr}$. Miller indices for the hexagonal $(\mathrm{H})$ and monoclinic $(\mathrm{M})$ materials are indicated. Red and black bars indicate the $\mathrm{Al}_{2} \mathrm{O}_{3}$ substrate and Pt current collector reflections. 
TABLE I. Lattice parameters obtained from Rietveld refinements of the XRD spectra.

\begin{tabular}{|c|c|c|c|c|}
\hline Material & a $(\AA)$ & $\mathrm{b}(\AA)$ & c $(\AA)$ & $\chi^{2}$ \\
\hline $\begin{array}{c}\mathrm{Na}_{0.6} \mathrm{MnO}_{2} \\
\text { Orthorhombic }(100 \%)\end{array}$ & 2.866 & 5.015 & 11.259 & 6.9 \\
\hline $\begin{array}{l}\mathrm{Na}_{0.6} \mathrm{MnO}_{2} \\
\text { Hexagonal }(100 \%)\end{array}$ & 2.876 & 2.876 & 11.261 & 7.9 \\
\hline $\begin{array}{c}\mathrm{Na}_{0.6} \mathrm{MnO}_{2} \quad 750 / 550^{\circ} \mathrm{C} \\
\text { Orthorhombic }(84 \%)\end{array}$ & 2.852 & 4.987 & 11.120 & 3.9 \\
\hline Hexagonal $(16 \%)$ & 2.842 & 2.842 & 11.236 & \\
\hline $\begin{array}{l}\mathrm{NaMnO}_{2} 750^{\circ} \mathrm{C} \\
\text { Monoclinic (97\%) }\end{array}$ & 5.619 & 2.849 & 5.773 & 10.3 \\
\hline Hexagonal (3 \%) & 2.876 & 2.876 & 11.195 & \\
\hline
\end{tabular}

The changes in Mn oxidation state have been studied using X-ray absorption near edge spectroscopy (XANES), Figure 5a. Qualitatively, it appears that $\mathrm{Mn}$ in $\mathrm{NaMnO}_{2}$ is more reduced than $\mathrm{Mn}$ in $\mathrm{Na}_{0.6} \mathrm{MnO}_{2}$ whereas the XANES of the $\mathrm{Na}_{0.6} \mathrm{MnO}_{2}$ films are nearly identical over the entire energy range. The lower edge energy for $\mathrm{NaMnO}_{2}$ is in agreement with the presence of a larger fraction of $\mathrm{Mn}^{3+}$ in the structure. Moreover, the nearly quasi-identical XANES for the $\mathrm{Na}_{0.6} \mathrm{MnO}_{2}$ films is in agreement with the XRD data and Rietveld refinements showing the predominate formation of the orthorhombic structure in both cases. Interestingly, the edge positions of the samples differ significantly from the reference compounds $\mathrm{Mn}_{2} \mathrm{O}_{3}$ and $\mathrm{MnO}_{2}$, and appear to be more positive than they expected. A precise description of the XANES is beyond the scope of this paper. Qualitatively, the edge energy depends on the formal cation oxidation state, the ligand electronegativity as well as lattice contributions. The presence of electropositive $\mathrm{Na}^{+}$may withdraw electron density from the $\mathrm{O}^{2-}$ anions, which may effectively create more oxidized Mn cations. In addition, the lattice contribution may influence the XANES.

The local coordination has been investigated by modelling the EXAFS functions of the spectra (Figure 5b, Table 2). In all cases, a relatively good agreement is found between the experimental and fitted data. The Fourier Transform of the EXAFS shows two main peaks around 1.5 and $2.5 \AA$ (not corrected for phase shift). The first peak is related to the coordination shell in the $\mathrm{MnO}_{6}$ octahedra whereas the second peak corresponds to $\mathrm{Mn}-\mathrm{Mn}$ and $\mathrm{Mn}-\mathrm{Na}$ interactions. The interatomic distances are obtained after fitting the data with the structural model for the corresponding structures (Table 2). In the case of the $\mathrm{Na}_{0.6} \mathrm{MnO}_{2}$ samples, the $\mathrm{Mn}-\mathrm{O}$ and $\mathrm{Mn}-\mathrm{Mn}$ coordination shells are found to be the same for both films, which can be related to their very close $a$ and $b$ lattice parameters ( $0.5 \%$ deviation, Table 1$)$. The Mn-Na shells, which indicate changes along the c direction, show significantly larger differences in agreement with the larger difference seen in c lattice parameter (Table 1). 
(a)

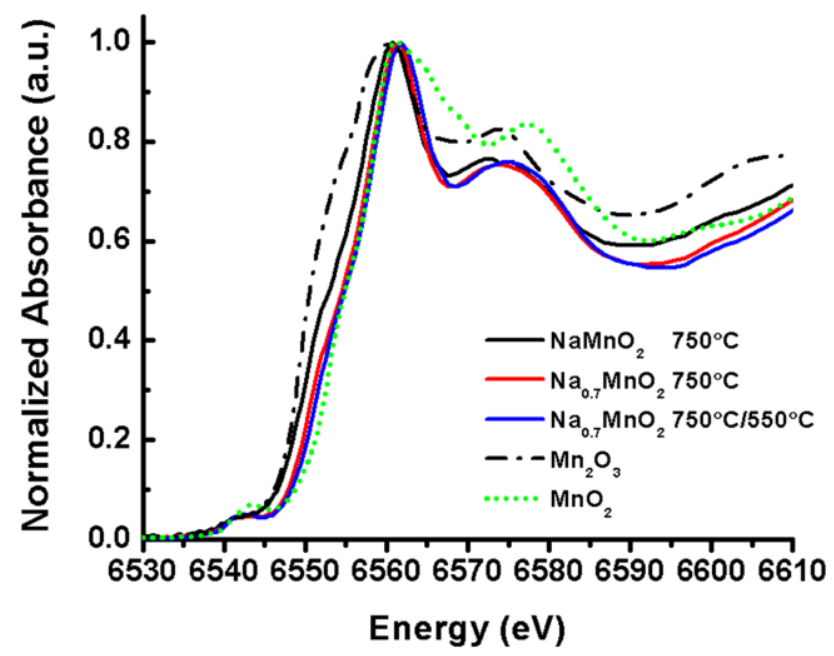

(b)

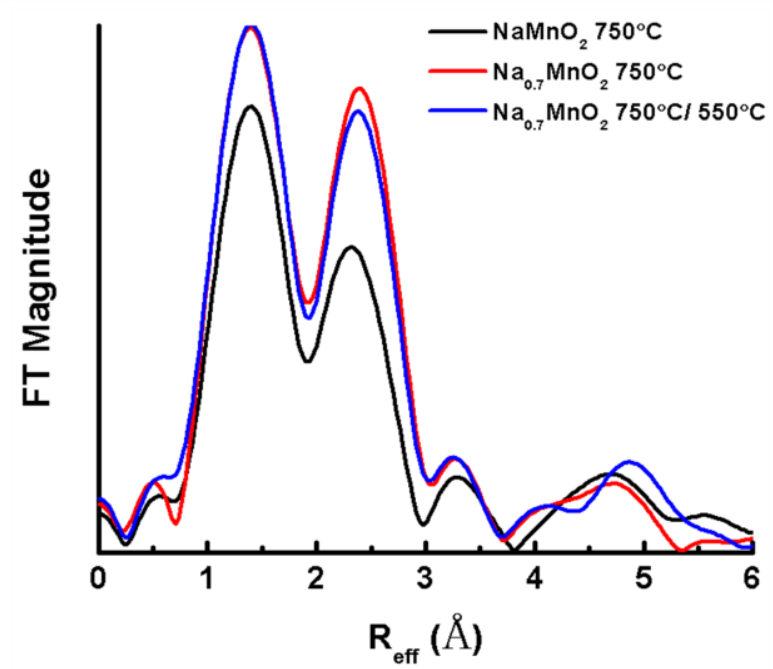

Figure 5. XAS data at Mn K-edge for the various thin films samples. (a) XANES and (b) $\mathrm{k}^{3}$-weighted Fourier transform EXAFS of the various thin film samples. The radial distance is not corrected for phase shift. $\mathrm{Mn}_{2} \mathrm{O}_{3}$ and $\mathrm{MnO}_{2}$ powder XANES measurements are added for reference.

TABLE 2. Interatomic distances and coordination numbers obtained after fitting the EXAFS data.

\begin{tabular}{cccccc} 
Sample & $\mathrm{X}-\mathrm{Y}$ pair & $\mathrm{R}(\AA)$ & $\mathrm{N}$ & $\sigma^{2}\left(\AA^{2}\right)$ & $\mathrm{R}$-factor \\
\hline $\mathrm{Na}_{0.6} \mathrm{MnO}_{2}$ & $\mathrm{Mn}-\mathrm{O} 1$ & 1.88 & 6 & 0.0034 & 0.0026 \\
$750^{\circ} \mathrm{C}$ & $\mathrm{Mn}-\mathrm{O} 2$ & - & - & - & \\
& $\mathrm{Mn}-\mathrm{Mn}$ & 2.88 & 6 & 0.0033 & \\
& $\mathrm{Mn}-\mathrm{Na} 1$ & 2.82 & 2 & 0.0118 & \\
\hline $\mathrm{Mn}-\mathrm{Na} 2$ & 3.28 & 6 & 0.0118 & \\
\hline $\mathrm{Na}_{0.6} \mathrm{MnO}_{2}$ & $\mathrm{Mn}-\mathrm{O} 1$ & 1.88 & 6 & 0.0036 & 0.0017 \\
$750 / 550^{\circ} \mathrm{C}$ & $\mathrm{Mn}-\mathrm{O} 2$ & - & - & - & \\
& $\mathrm{Mn}-\mathrm{Mn}$ & 2.88 & 6 & 0.0073 & \\
& $\mathrm{Mn}-\mathrm{Na} 1$ & 2.72 & 2 & 0.0076 & \\
\hline $\mathrm{NaMnO}$ & $\mathrm{Mn}-\mathrm{Na} 2$ & 3.20 & 6 & 0.0065 & \\
$750^{\circ} \mathrm{C}$ & $\mathrm{Mn}-\mathrm{O} 1$ & 1.88 & 4 & 0.0078 & \\
& $\mathrm{Mn}-\mathrm{O} 2$ & 2.11 & 2 & 0.0033 & \\
& $\mathrm{Mn}-\mathrm{Mn}$ & 2.63 & 2 & 0.0290 & \\
& $\mathrm{Mn}-\mathrm{Na} 1$ & 2.91 & 2 & 0.0290 & \\
\hline
\end{tabular}


The electrochemical properties of these thin films are presented in Figure 6. The profiles during the first charge show a small capacity, as expected from the desodiation up to $3.5 \mathrm{~V}$ (7-9). The subsequent discharge (sodiation) a steady sloping profile until an inflection around 2.2-2.3 $\mathrm{V}$ is measured. The second charge essentially shows the reversible processes with a plateau around $2.3 \mathrm{~V}$ and a slope until $3.5 \mathrm{~V}$, whereas the second discharge is identical to the first. Several small inflections are visible in the profiles. These features are less pronounced than for the powder counterparts (7-9), which indicates that the films electrode structures deviates somewhat from the ideal structures that can be achieved by solid-state powder synthesis. This difference may result from defects such as, perhaps twinning or stacking faults, a topic of future studies. The $\mathrm{Na}_{0.6} \mathrm{MnO}_{2}$ films annealed at $750^{\circ} \mathrm{C}$ show the most favorable potential profile with a significantly higher operating voltage. The films show storage capacities around 50-60 $\mu \mathrm{Ah} \mathrm{cm}^{-2} \mu \mathrm{m}^{-1}$, which correspond to specific capacities near $120-140 \mathrm{mAh} \mathrm{g}^{-1}$ assuming the expected bulk densities of around 4.1-4.25 $\mathrm{g} \mathrm{cm}^{-3}$ for the $\mathrm{Na}_{\mathrm{x}} \mathrm{MnO}_{2}$ parent materials. As indicated in Figure $6 b$ the material can be reversibly cycled many times, which opens a route to study the properties of $\mathrm{Na}$-ion thin film cathodes as model systems, or for the fabrication of Na-ion thin film solid-state microbatteries.
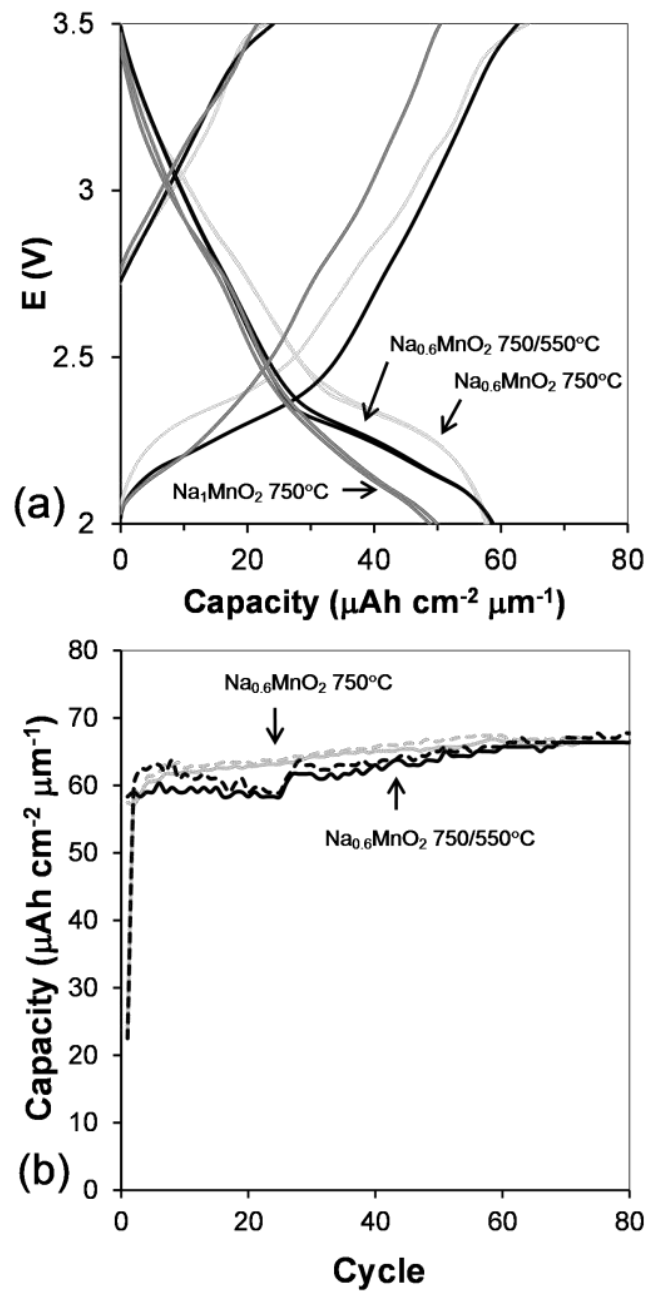

Figure 6. (a) Electrochemical potential profiles during the first two cycles and (b) cycle life for $\mathrm{Na}_{0.6} \mathrm{MnO}_{2} 750^{\circ} \mathrm{C} 1 \mathrm{hr}$ (light grey), $\mathrm{Na}_{0.6} \mathrm{MnO}_{2} 750^{\circ} \mathrm{C} / 550^{\circ} \mathrm{C}$ (dark grey) and $\mathrm{NaMnO}_{2} 750^{\circ} \mathrm{C}$ (black) thin film electrodes. 


\section{Conclusions}

Thin films of $\mathrm{Na}_{0.6} \mathrm{MnO}_{2}$ and $\mathrm{Na}_{1.0} \mathrm{MnO}_{2}$ have been successfully synthetized by magnetron sputtering and post-annealing at high temperatures under various conditions. The thin films cathodes are characterized by potential profiles fairly similar to the powder samples, and exhibit reversible storage capacities around 50-60 $\mu \mathrm{Ah} \mathrm{cm}^{-2} \mu \mathrm{m}^{-1}$, which correspond to about 120-140 mAh g ${ }^{-1}$. The resulting $\mathrm{Na}_{0.6} \mathrm{MnO}_{2}$ films contain either a hexagonal $(\mathrm{P} 2)$ or orthorhombic structures while the $\mathrm{Na}_{1.0} \mathrm{MnO}_{2}$ adopts a monoclinic structure $\left(\mathrm{O}^{\prime} 3\right)$. These results open a route to the exploration of $\mathrm{Na}$-ion cathode thin films to be used as model systems or for the fabrication of rechargeable solid-state microbatteries based on $\mathrm{Na}$-ion chemistries.

\section{Acknowledgments}

LB, RRU, CAB and GMV were supported by the U.S. Department of Energy's Office of Basic Energy Science (DOE-BES), Division of Materials Sciences and Engineering, under contract with UT-Battelle, LLC. Microscopy research was also supported by ORNL SHaRE user facility, which is sponsored by the Scientific User Facilities Division, Office of Basic Energy Sciences (BES), U.S. Department of Energy (DOE). XAS experiments were conducted at the National Synchrotron Light Source, Brookhaven National Laboratory, supported by the US Department of Energy, Office of Science, Office of Basic Energy Sciences, under Contract No. DE-AC02-98CH10886. KJC and YSM acknowledge support from the National Science Foundation under Award Number DMR105717.

\section{References}

1. M. Armand, J.-M. Tarascon, Nature, 451, 652 (2008).

2. B. Dunn, H. Kamath, J.-M. Tarascon, Science, 334, 928 (2011).

3. N. Yabuuchi, M. Kajiyama, J. Iwatate, H. Nishikawa, S. Hitomi, R. Okuyama, R. Yasuhiro, S. Komaba, Nature Materials, 11, 521 (2012).

4. C. Delmas, J.-J. Braconnier, C. Fouassier, P. Hagenmuller, Solid State Ionics, 3/4, 165 (1981).

5. Z. Lu, J.R. Dahn, J. Electrochem. Soc., 148, A1225 (2001).

6. J.-P. Parant, R. Olazcuaga, M. Devalette, C. Fouassier, P. Hagenmuller, J. SolidState Chem., 3, 1 (1971).

7. A. Mendiboure, C. Delmas, P. Hagenmuller, J. Solid-State Chem., 57, 323 (1985).

8. A. Caballero, L. Hernán, J. Morales, L. Sánchez, J. Santos Pena, M.A.G. Aranda, J. Mater. Chem., 12, 1142 (2002).

9. Z. Ma, H. Chen, G. Ceder, J. Electrochem. Soc., 158, A1307 (2011).

10. M. Newville, J. Synchrotron Rad., 8, 322 (2001).

11. B. Ravel, M. Newville, J.Synchrotron Rad., 12, 537 (2005).

12. J.J. Rehr, R.C. Albers, Rev. Mod. Phys., 72, 621 (2000).

13. A.D. Tevar, J.F. Whitacre, J. Electrochem. Soc., 158, A870 (2010).

14. L. Baggetto, R.R. Unocic, N.J. Dudney, G.M. Veith, J. Power Sources, 211, 108 (2012).

15. J. Fischer, C. Adelhelm, T. Bergfeldt, K. Chang, C. Ziebert, H. Leiste, M. Stüber, S. Ulrich, D. Music, B. Hallstedt, H.J. Seifert, Thin Solid films, 528, 217 (2013). 